\title{
Od okupacji do pandemii. O wariantach piosenki Siekiera, motyka i jej roli w sytuacjach traumatycznych
}

\author{
From occupation to pandemic: \\ On the variants of song Siekiera, motyka \\ and their role in traumatic situations
}

DOI: $10.12775 /$ LL.4.2021.003 | CC BY-ND 4.o

ABSTRACT: The aim of this article is to present the life (cycle) of the song entitled Siekiera, motyka... and the role it plays in Polish culture in traumatic situations. During World War II, numerous variants of this song were sung by street performers. After the end of the war the song became popular thanks to the 1946 film Zakazane piosenki (Forbidden Songs), and its wartime versions were later used by many artists. Subsequent contrafacta of Siekiera appeared in the Polish People's Republic, especially during martial law, as a manifestation of the resistance against communist government, hence the strong associations of the song with the resistance movement. The Siekiera, motyka incipit is still used to create rhymes commenting on contemporary events, published on the Internet. New versions of Siekiera, motyka have been created in response to the coronavirus pandemic. In this case, the enemy, instead of the German occupier and the communist regime, has been the virus. The versions from different times share many features in common - e.g. they are strongly rooted in contemporary reality, evoking the names of well-known figures and humorous wording. They appear in situations of social tension, disorganisation, and they serve to help people come to terms with new reality and traumatic experiences.

KEYWORDS: street song, occupation folklore, political folklore, martial law, opposition, trauma, pandemic 
Wiosną 2020 r., gdy pandemia koronawirusa zmusiła Polaków do odbycia „narodowej kwarantanny”, w internecie pojawiły się wierszyki, żarty, memy, rysunkowe dowcipy komentujące tę trudną sytuację. Co ciekawe, wiele z nich parafrazowało stara piosenkę Siekiera, motyka. Jej incipit, schemat i melodia często powracają w kryzysowych momentach historii Polski, służą do komentowania, wyśmiewania, a przede wszystkim oswajania nowej rzeczywistości. Głównym celem niniejszego artykułu jest prezentacja wybranych wariantów tej piosenki oraz analiza funkcji, jakie spełniała i spełnia ona od lat okupacji aż do dzisiaj.

Wielu Polaków, szczególnie starsze pokolenie, zna omawiany utwór z filmu Zakazane piosenki w reżyserii Leona Buczkowskiego z 1946 r. W obrazie tym poświęconym antyniemieckiej twórczości muzycznej w czasach II wojny światowej jest on zaprezentowany jako jeden z wielu wykonywanych przez ulicznych śpiewaków i podwórkowe orkiestry. To właśnie dzięki filmowi Buczkowskiego piosenki okupowanej Warszawy stały się popularne w całej Polsce. Jednak spośród wszystkich wykorzystanych w filmie utworów, żaden nie funkcjonował w tak licznych wariantach i nie wykazał się taką żywotnością jak Siekiera, motyka, nie tylko w latach wojny, ale i w czasach późniejszych.

Folklor okupacyjny, do którego zalicza się Siekiera, motyka, doczekał się licznych omówieni i opracowań. Aleksander Jackowski pisał, że w czasie II wojny światowej kawały, piosenki, karykatury

pomagały żyć, pomagały przetrwać. Ośmieszając wroga - czyniły go mniej strasznym, wykpiwając pozwalały poczuć się silniejszym. Piosenki czy celne zdania [...] stawały się bezimienne, powszechnie znane, powtarzane. Celna, zwięzła forma, nawiązująca zarówno do folkloru wiejskiego, jak i do twórczości kabaretowej, pozwalały na wręcz błyskawiczną karierę takich piosenek czy dowcipów, na ich popularność, jako tworów anonimowych. Dodałbym jeszcze - anonimowych nie tylko dlatego, że puszczano je w obieg bez podania nazwiska autora, ale i z tego powodu, że wyrażały to, co każdy czuł, co chciał usłyszeć. Anonimowość była wówczas przejawem powszechności (Jackowski 1990: 11).

Podczas wojny Siekierę, motykę śpiewano nie tylko w Warszawie, ale i w innych miastach Generalnej Guberni, a także w oddziałach partyzanckich (Siekiera 1). Szczególnie ważna była jednak dla mieszkańców stolicy. Aktorka Alina Janowska po raz pierwszy usłyszała ją w EKD, czyli Elektrycznej Kolejce Dojazdowej, gdzie częstymi gośćmi byli rozmaici śpiewacy i orkiestry podwórkowe: muzykanci z banjo, skrzypcami, akordeonem i „zapiewajło”, który jednocześnie dyrygował i zbierał datki od słuchaczy. W książce Opowieść o piosence Janowska pisała: „W czasie którejś z moich codziennych podróży usłyszałam po raz pierwszy piosenkę Siekiera, motyka, piłka, graca. Melodię znałam jeszcze sprzed wojny. Tata ją czasem śpiewał. Ale tym razem słowa były całkiem inne!” (Szymalski 1986: 118). 
Tomasz Szarota uznał piosenkę Siekiera, motyka za jedną z najpopularniejszych w wojennej Warszawie:

Jej odmiana okupacyjna powstała jesienią 1942 roku, potem piosenka kilkakrotnie ulegała przekształceniom, dochodziły coraz to nowe zwrotki, wykonawcy śpiewali ją w różnych wersjach, chyba często wprowadzając własne innowacje. Dopiero przygotowując do druku obecne, czwarte wydanie niniejszej książki, dowiedziałem się, kto był autorem słów owego ulicznego „przeboju”. Napisała je Anna Jachnina, współautorka konspiracyjnej broszury Anegdota $i$ dowcip wojenny, na zlecenia szefa komórki Sztuka - Aleksandra Kamińskiego, z przeznaczeniem dla śpiewaków ulicznych. Jachnina, aresztowana 3 listopada 1942 roku, była potem więziona w obozach koncentracyjnych Auschwitz i Ravensbrück. Tekst piosenki opublikowano po raz pierwszy w zbiorku Postuchajcie, ludzie..., wydanym w lutym 1943 roku (Szarota 2010: 298)․․

W przywołanej powyżej publikacji tekst piosenki brzmi następująco:

Siekiera, motyka, bimber szklanka, W nocy nalot, w dzień łapanka.

Siekiera, motyka, piłka, młot, Drałuj draniu, wreszcie stąd.

Kolejka, riksza, tramwaj, buda, Każdy zwiewa, gdzie się uda, Bo po co kukać w cytadeli, Albo w jakiej innej celi.

1 Faktycznie do 2010 r. wszystkie wersje piosenki funkcjonowały jako dzieła anonimowe. Anna Jachnina nie robiła co prawda tajemnicy z tego, że to ona wpadła na pomysł napisania nowych słów do popularnej melodii, ale informacje te nie rozpowszechniły się w publicznym obiegu. W wywiadzie udzielonym dziennikarce czasopisma „Czas” w 1975 r. Jachnina mówiła: „Mieszkałam wówczas na ulicy Francuskiej w Warszawie. Była zima, mróz w mieszkaniu i we mnie - w środku. Straszliwy głód. Otrzymałam właśnie polecenie napisania tekstów - wierszyków, piosenek dla naszych ulicznych sojuszników - gazeciarzy, kwiaciarek, muzykantów. Ołówek wypadał ze zgrabiałych rąk, mózg zamarzał. Nie było światła, tylko jakiś knocik, lampeczka... To była noc tworzenia w stanie zamrożonym. Chyba właśnie wtedy - już dokładnie nie pamiętam - powstała ta piosenka: Siekiera, motyka, piłka, szklanka, w nocy nalot, w dzień łapanka...” (Jachnina, Woźniak 1975: 24). Dopiero w 2010 r. rodzina Anny Jachniny, przeglądając archiwalne dokumenty, natrafiła na materiały świadczące o tym, że to ona jest autorką słów popularnej wersji piosenki. Jej wnuk Wojciech Jachna opowiada: „Ta piosenka jest jak hymn, jest wszędzie, nawet w Misiu. Jest symbolem ruchu oporu, jak kotwica Polski Walczącej”. Równocześnie stara się wyjaśnić, dlaczego autorstwo utworu przez tak wiele lat stanowiło tajemnicę: „Babcia była strasznie przekorna i jednocześnie skromna. Może uznała, że nie należą się jej prawa do tego tekstu? Prawdopodobnie nie wymyśliła go od podstaw, ale spisała to, co już śpiewała ulica, uporządkowała, dodała coś od siebie... Ale mogę się tylko domyślać, bo nie zdążyłem z nią o tym porozmawiać” (Szubrycht 2020). 
Już nie wiadomo, gdzie się schować,

Chcą nas z domu wyszabrować,

A po ulicy gonią wciąż,

Jakby tu jeszcze kogo wziąć.

Szczęściem kultura nie zabrania

Dać po uchu, jakem cwaniak,

Dobrze że kulturę w garści mam

I po d.... szwabom dam (Posłuchajcie 1943: 3-4).

Zamieszczona w tej publikacji wersja jest mniej znana. Inna, bardziej popularna, pojawiła się 1947 r. w zbiorze Warszawski dowcip w walce 1939-1944, opracowanym przez Mariana Ruth Buczkowskiego, który podczas okupacji współpracował z Jachniną w Biurze Informacji i Propagandy Armii Krajowej, w komórce Sztuka.

Siekiera, motyka, bimbru szklanka,

W nocy nalot, w dzień łapanka.

Siekiera, motyka, piłka, blok,

Świnia, glina, bydlę, szkop.

$[\ldots]$

Siekiera, motyka, światło, prąd,

Kiedyż oni pójdą stąd.

Piwo, bimber, wino, alasz,

Przegrał wojnę głupi malarz.

Siekiera, motyka, piłka, nóż

Przegrał wojnę już, już, już! (Ruth Buczkowski 1947: 65)

Okupacyjnych wersji Siekiery, motyki powstało wiele. Do „bazy”, jaką prawdopodobnie stanowiła piosenka Jachniny, dopisywano nowe zwrotki, przerabiano istniejące, podmieniano słowa i zwroty. Te różne warianty były po wojnie wielokrotnie publikowane, np. w zbiorach Śmiech w kajdanach. Kawaty warszawskie w czasach okupacji (Straszewicz 1946), Satyra w konspiracji (Załęski 1958), Gwara warszawska dawniej i dziś (Wieczorkiewicz 1974), Złota księga pieśni polskich (Adrjański 1997) i wielu innych. Pewne strofy powtarzały się, inne występowały tylko w jednym konkretnym wydaniu.

Piosenka stała się częścią warszawskiego folkloru i weszła do repertuaru artystów z nim związanych: Stanisława Grzesiuka, Kapeli Czerniakowskiej, Staśka Wielanka i Kapeli Warszawskiej. W latach 1967-2007 pojawiła się na dziewięciu płytach tych wykonawców (Siekiera 1). Siekiera motyka była też chętnie interpretowana w nurcie tzw. muzyki biesiadnej i chodnikowej, np. przez jeden 
z najstarszych zespołów disco-polo Big Dance, który wydał całą płytę z „zakazanymi piosenkami” (Siekiera 2003). Utwór cytowali bądź parafrazowali także raper Tede (A pamiętasz jak) (Siekiera 2003), zespoły Lao Che (Godzina W) (Siekiera 10) oraz Piersi (Marsz KPN) (Siekiera 11). W 2014 r. utwór przypomniało Warszawskie Combo Taneczne Janka Młynarskiego na swoim debiutanckim albumie Przyznaj się (Dubrowska 2017). Warto zauważyć, że współcześnie po piosenkę Siekiera, motyka sięgają zespoły, które tworzą w obszarze kultury nie związanym z folklorem i dzięki temu, podobnie jak było w przypadku filmu Zakazane piosenki, trafia ona do szerszego kręgu odbiorców. Okupacyjne wersje znaleźć można także w na wielu stronach internetowych (np. teksty.org, maluchy.pl, staremelodie.pl).

Melodia i incipit okupacyjnego przeboju nie pochodzą z lat 4o. XX w. Powstał on na bazie piosenki z 1917 r., rozpoczynającej się wersami: „Co użyjem to dla nas, / bo za sto lat nie będzie nas! / Siekiera, motyka, piłka, kleszcze, / chodźże Maniu, zatańcz jeszcze...” (Siekiera 1). Jej słowa wraz z nutami znaleźć można w śpiewnikach z lat międzywojennych. Już wówczas występowała w różnych, ale niewiele się różniących wariantach i publikowana była jako piosenka żołnierska (Prosiłem 1920: 3-4). Teksty mają charakter żartobliwy, frywolny i opowiadają o dziewczynie, Marysi lub Mańce, odrzucającej w kolejnych zwrotkach awanse adoratorów: ułana, sapera, lotnika, cywila. Wersje Siekiery, motyki, podobnie jak wiele pieśni ludowych, miewały charakter tasiemcowy: w książce Wiersze żotnierskie z 1938 r. zamieszczono aż 27 zwrotek autorstwa plutonowego rezerwy Aleksandra Fuska z Nowego Targu (Siekiera 1).

Piosenkę z różnymi wariantami tekstu wykonywali przedwojenni artyści, np. Andrzej Bogucki, Mieczysław Borowy, Ignacy Ulatowski. Chór Juranda na płycie z 1934 r. śpiewał ją ze słowami nostalgiczno-refleksyjnymi, gdzie głównym tematem było przemijanie smutnego życia i zachęta do korzystania z jego uroków „póki czas”. W swym repertuarze zespół miał także „wersję pijacką, której fragment był taki:

Siekiera, motyka, piłka kleszcze, chętnie coś wypiłbym jeszcze.

Siekiera, motyka, kółko, pas,

Przepij do mnie jeszcze raz.

Siekiera, motyka, piłka, kolej, tutaj polej, tutaj dolej... (Siekiera 8).

Już wówczas utwór wykorzystywano do tworzenia nowych strof, których celem było komentowanie bieżącej rzeczywistości. W tygodniku polityczno-satyrycznym „Żółta Mucha Tse-Tse”, w numerze poświęconym podatkom i podatnikom z 1932 r., opublikowano trzyzwrotkową Polkę siedzonkę, nawiązującą tekstem do ówczesnych kontekstów społeczno-ekonomicznych, dziś już niezrozumiałych. W tym przypadku utwór ma specyficzną cechę, widoczną również w wielu 
późniejszych wariantach, a mianowicie jest tak silnie osadzony w bieżących realiach, że po jakimś czasie przestaje być aktualny i odchodzi w zapomnienie:

Siekiera, motyka, piłka, kołek

Twardy jest rządowy stołek

Siekiera, motyka, piłka, gwóźdź,

Więc go „Bebku” w trąbę puść! (Polka siedzonka 1932: 3)

Piosenkę, a konkretnie jej wersję żołnierską, znała też amerykańska polonia. W 1928 r. w Chicago ukazała się płyta, na której zamieszczono utwór pt. Co użyjem to dla nas (Everything we do is good for us) w wykonaniu Pawła Fauta i „grupy polskich artystów”. Śpiewany przez nich tekst był niemalże identyczny z tekstem piosenki ze śpiewnika z 1920 r. W 1947 r. w Nowym Jorku wydano kolejną płytę z piosenką Siekiera, motyka - polka (The hatchet and the hoe) w wykonaniu Franka Wojnarowskiego i jego orkiestry. Ta wersja różniła się od poprzedniej - muzycy zagrali ją w bardziej tanecznym rytmie, a wokalista zaśpiewał tylko trzy wybrane zwrotki przedwojennej wersji (Siekiera 9).

Po II wojnie światowej, niejako równolegle $\mathrm{z}$ cały czas popularnymi wersjami okupacyjnymi, zaczęły pojawiać się nowe, związane z ówczesnymi realiami. W 1945 r. kolejną, jedenastozwrotkową kontrafakturę piosenki nagrał w Polskich Zakładach Fonograficznych „Odeon” Polski Kwartet Ludowo-Narodowy. Autor słów tej biesiadno-żartobliwej wersji jest nieznany, a jej treść dotyczy głównie dość specyficznych relacji damsko-męskich:

Siekiera, motyka, piłka, deska,

Szaflik, kubeł i czterdziestka,

Siekiera, motyka, piłka, drut,

Nie bądź głupia jak ten but.

Ach z moją Mańką to jest fajne życie,

Tańczy się polkę jak po aksamicie,

Czasem ci w zęby zajedzie kułakiem,

Ty elegancko zrewanżuj się kopniakiem (Siekiera 8).

Popularność wersji okupacyjnych i postrzeganie ich jako symbolu walki z wrogiem miały wpływ na to, że zaczęto odwoływać się do nich w latach 8o. XX w. Nowe kontrafaktury traktowano jako przejawy walki z komunistyczną władzą. Katarzyna Anna Głuszak zauważyła, że:

w okresie utraty niepodległości muzyka i piosenka stanowiły spoiwo narodu. W czasie Polskiej Rzeczypospolitej Ludowej stawały się wyrazem zjednoczenia przeciwko władzom państwowym. Znamienny jest fakt, że mimo upływu lat, w Polsce powojennej śpiewano niejednokrotnie te same pieśni, które odgrywały kluczową rolę dla narodu przed wielu laty. 
Świadczy to o tym, jak nierozerwalna jest więź pieśni z życiem narodu, jak splecione są ze sobą życie i sztuka. Pieśni patriotyczne, partyzanckie, a nawet religijne, przez wieki powracały, dodając Polakom wiary w zwycięstwo, dając im poczucie jedności narodowej [...]. Utwory powstawały poprzez dopisywanie aktualnych, często prześmiewczych treści do znanych melodii, czy nawet przez nieznaczne modyfikowanie znanych piosenek. Szczególnie owocne było przerabianie okupacyjnej piosenki Siekiera, motyka, która dawała ogromne pole do zmian i lirycznych popisów (Głuszak 2014: 3, 187).

W stanie wojennym (1981-1983) chętnie odwoływano się do retoryki pieśni narodowych i żołnierskich okresu I i II wojny światowej. Inspiracji szukano także w piosenkach ludowych oraz polskich przebojach muzyki rozrywkowej popularnych w latach 70. XX w. Znana melodia służyła jako wzorzec meliczny, a utrwalony w powszechnej pamięci historyczny tekst stawał się źródłem inspiracji (Skoczek 2001: 510).

Liczne kontrafaktury wielu piosenek, w tym też Siekiery, motyki, powstawały w obozach dla internowanych. Ich zbiór ukazał się w 1982 r., a wydała go redakcja „Skrótu”, podziemnego pisma dla osadzonych, które ukazywało się raz na dwa miesiące w 1982 r. i dostarczane było początkowo do kilku, a ostatecznie do wszystkich obozów. Zeszyt zatytułowany Głosy zza muru, w którym zebrano wiersze i pieśni, opublikowano po raz drugi w $1984 \mathrm{r}$. Opatrzono go wstępem przybliżającym sytuację tworzenia i wykonywania piosenek. Czytamy tam m.in., że śpiewano je we wszystkich obozach, chociaż groziły za to restrykcje, gdyż uznawano to za „szkalowanie ustroju PRL w miejscu publicznym” (Głosy 1984: 5). Autor zbioru spisywał teksty z rękopisów lub taśm magnetofonowych. Zauważył, że tekst tej samej piosenki śpiewany w różnych obozach znacznie odbiegał od autorskiego pierwowzoru. Oprócz utworów oryginalnych, autorskich, najczęściej anonimowych, powstałych w stanie wojennym, w zbiorze zamieszczono stare pieśni religijne i patriotyczne oraz piosenki z czasów I i II wojny światowej. Czasem śpiewano je w wersji oryginalnej, kiedy indziej ze zmienionym tekstem. W obozach powstawały różne kontrafaktury tego samego utworu, np. do melodii pieśni Gustawa Ehrenberga Szlachta w roku 1831 i jej incipitu „Gdy naród do boju wystąpił z orężem” nowe słowa napisano w obozie w Opolu, a inne w Nowym Łupkowie. Dużą popularnością cieszyła się też Rota, której wersje z lat 8o. XX w. nosiły tytuły Rota Solidarności i Rota obozowa, a także melodia pieśni My pierwsza brygada (Głosy 1984: 5).

Oprócz nowych wersji piosenek okupacyjnych, takich jak Okupacyjna piosenka (na melodię Teraz jest wojna, z incipitem „Są czołgi, armaty, więzienia i kraty...”), Trzynastego grudnia roku pamiętnego (na melodię piosenki Dnia pierwszego września) jest też Siekiera, motyka, zamieszczona w rozdziale pt. Pieśni sowizdrzalskie (żartobliwe-ironiczne-szydercze) i opatrzona wyjaśnieniem dotyczący miejsca jej powstania: „Nowy tekst okupacyjnej piosenki śpiewanej w Kwidzynie. Powstał jednak w innym miejscu, być może w Białołęce” (Głosy 
1984: 73). Tekst ośmiozwrotkowej piosenki oparto głównie na zestawieniach: Jaruzelskiego z dyktatorami Pinochetem i Pol Potem, Placu Centralnego z Placem Czerwonym, orła $\mathrm{z}$ wroną ${ }^{2}$. Jej wymowa jest optymistyczna i niesie wiare w zwycięstwo nad komunistycznym reżimem. Wybrane zwrotki tego tekstu brzmią tak:

Siekiera, motyka, stan wojenny,

Naród nie jest taki ciemny.

Ostre szpony i korona,

Nie pokona orła wrona.

Siekiera, motyka, smok wawelski,

Przegra wojnę Jaruzelski.

Siekiera, motyka, ZOMO, gwóźdź,

Przegra wojnę no i już! (Głosy 1984: 73).

Inną wersję piosenki przytacza Anna Skoczek, stwierdzając zarazem:

Nieskomplikowany zabieg włożenia własnego tekstu w gotową strukturę wersyfikacyjną, powielenie rytmiki, przejęcie rekwizytów i leksyki wojennej, zaowocował powstaniem sporej liczby kontrafaktur innej okupacyjnej piosenki Siekiera, motyka. Powszechnie znana melodia służyła popularyzacji treści utworu:

Siekiera, motyka, katar sienny

Mamy w Polsce stan wojenny,

Siekiera, motyka, gaz i prąd,

Kiedy oni pójdą stąd?

Siekiera, motyka, bimber, szklanka,

Na pochody jest lapanka,

ZOMO, pały, woda, gaz,

Lecz to nie przeraża nas (Skoczek 2001: 518).

Incipit piosenki wykorzystał też autor napisu na murze, który połączył wersy z wersji mu współczesnej i okupacyjnej, nie zważając na brak rymu i sensu: „Siekiera, motyka, Smok wawelski, Przegra wojnę Głupi malarz”. Wojciech Łysiak $\mathrm{w}$ artykule, $\mathrm{z}$ którego pochodzi powyższy tekst, uznał wprowadzenie stanu wojennego za „wielką inspirację folklorystyczną”. Przytaczając powyższy przykład zauważył, że „napisy tego rodzaju zorientowane były na rozładowanie ponurej atmosfery, na poprawę samopoczucia i podkreślenia, że duch w narodzie jeszcze żyje” (Łysiak 1990: 18).

2 WRON - Wojskowa Rada Ocalenia Narodowego 
Powszechne skojarzenie piosenki z działalnością opozycyjną miało zapewne wpływ na to, że jej melodia grana na flecie rozpoczynała audycje Radia Solidarność. W 1989 r., na łamach „Gazety Wyborczej” pracownicy rozgłośni wspominali:

Minęło już ponad siedem lat od chwili, kiedy w eterze po raz pierwszy zabrzmiały dźwięki fujarki na melodię: Siekiera, motyka, piłka, szklanka... W kwietniu 1982 roku była to w Warszawie prawdziwa sensacja. Miasto odpowiedziało migotaniem tysięcy świateł, ludzie wyszli przed domy, ściskali się, całowali... Służby przeznaczenia specjalnego również szalały - używając wszelkich możliwych środków, chciały wykryć nadajnik. Bezskutecznie. Zastosowano więc inne rozwiązanie. Gdy tylko w eterze zabrzmiały pierwsze dźwięki sygnału, znacznie silniejszy nadajnik dostrajał się do naszej fali i słychać już było tylko muzykę Beatlesów (Siekiera, motyka 1989: 4).

O tym, że piosenka cały czas jest kojarzona z ruchem oporu, może świadczyć pojawienie się jej w popularnym serialu Ranczo, w jednym z odcinków siódmego sezonu, opowiadającym o „konspiracyjnej” działalności niektórych mieszkańców Wilkowyj związanej z aresztowaniem wójt Lucy Wilskiej. Autorem słów tej wersji piosenki był scenarzysta filmu Robert Brutter, a zaczynała się ona tak:

Siekiera, motyka, bimber, brona,

Nikt Wilkowyj nie pokona,

Siekiera, motyka, w płocie dziura,

Przegra tu prokuratura (Adamczyk, Brutter 2013).

Incipit „Siekiera, motyka...” jest nadal wykorzystywany do tworzenia rymowanek komentujących współczesne wydarzenia. Nawet niewprawny wierszokleta potrafi dopisać do niego nowe wersy. Wiele $\mathrm{z}$ nich można znaleźć $\mathrm{w}$ internecie, czasem pojawiają się po prostu w odpowiedzi na hasło rzucone ad hoc przez któregoś z internautów, np. „Znacie jakieś rymowanki do Siekiera, motyka?” (Siekiera 7) bądź „Tworzymy nowe piosenki przeróbki znanych” (Siekiera 6). Efektem są liczne zwrotki, najczęściej będące wyrazem niezadowolenia autorów z działań polityków, np.:

Siekiera, motyka, skrzynki, wory, Wszyscy idą na wybory.

Siekiera, motyka, czacha, mózg,

Znów Kaczyński i znów Tusk.

Jeden chciałby wszystkich zabić, Drugi wszystkim w dupę włazić, Siekiera, motyka, trumna, gwóźdź, Teraz sobie wybierz cós (Siekiera 7). 
Siekiera, motyka, imigracja, W diabły poszła demokracja, Siekiera, motyka, czarny ptak, Wolne media trafił szlag (Siekiera 6).

Około 30 dwuwersowych rymowanek znalazło się w komentarzu do artykułu dotyczącego protestów pod sądami, opublikowanego w 2017 r. na portalu trojmiasto.pl. Wierszyki nie wiązały się bezpośrednio z treścią tekstu, a wyrażały po prostu ogólną dezaprobate wobec polskich realiów politycznych i ekonomicznych. Oto kilka przykładów takich dwuwersów:

Siekiera motyka, riksza buda, Do Londynu jak się uda.

Już nie mamyyyyy, gdzie się skryć,

Kaczki nam nie dają żyć.

Ich kultura nie zabrania,

Zmuszać ludzi do żebrania.

Siekiera, motyka, funt kiełbasy,

Nauczyciel nie ma kasy.

Siekiera, motyka, talerz kaszy,

A lekarze do kamaszy.

Siekiera, motyka, burak, koń,

A wykształciuch - z kraju won! (Siekiera 12).

Pojawiające się w tym zestawie tekstów nazwiska polityków i odniesienia do konkretnych wydarzeń świadczą o tym, że niektóre z rymowanek mogły powstać wiele lat wcześniej, np.:

Siekiera, motyka, pałka, Dorn,

Because of Piłka we have no porn!

Siekiera, motyka, sex-afera,

Niezły buhaj jest z Leppera.

Siekiera, motyka, sznurek, budka, Jak może być zgwałcona prostytutka (Siekiera 12). 
Współczesne wydarzenia cały czas dostarczają tematów do tworzenia nowych zwrotek piosenki. Miejscem ich publikacji są np. portale społecznościowe Facebook i Twitter, a także strona demotywatory.pl ${ }^{3}$. Tu rymowanki pojawiają się w rysunkach, memach bądź komentarzach. Inspiracją dla autorów był np. marsz niepodległości z 2017 r.:

Siekiera, motyka, kulson, pała,

Nie daj z siebie robić wała,

Suka, radiowóz, woda, gaz,

Chawu depe i jeszcze raz (Siekiera 4);

podział dotacji z Ministerstwa Kultury w 2020 r.:

Siekiera, motyka, celebryta,

Cała flaszka już wypita,

Ministrze kultury, bardzo proszem,

Wspomóż sztukę, sypnij groszem (Siekiera 4);

czy działalność jednej ze znanych przeciwniczek aborcji w 2020 r.:

Siekiera, motyka, jestem Godek,

Każę rodzić każdy płodek (Siekiera 3).

Autorzy tych zwrotek wpisują się swoją twórczością w tezę Aleksandra Jackowskiego, który twierdził, że „w kraju surrealistycznym [...] śmiech jest odtrutką, pełni role katharsis. Rozładowuje gniew, ale i zapobiega znieczuleniu na absurdy. Każe je dostrzegać, a to jest ważne" (Jackowski 1990: 12).

Nowe wersje Siekiery, motyki powstały również w 2020 r. w związku z pandemią koronawirusa i tzw. narodową kwarantanną. Konieczność ciągłego przebywania w domu wyzwoliła w niektórych Polakach rymotwórcze talenty, w związku z czym w internecie pojawiło się wiele wierszyków, memów i rysunków poświęconych nowej, trudnej sytuacji. Niektóre z nich wykorzystywały incipit „Siekiera, motyka...” w niespotykanym dotąd kontekście. Prawdopodobnie ich twórcy, świadomie lub nie, odwoływali się do okupacyjnej funkcji piosenki jako narzędzia walki z wrogiem. W tym przypadku okupanta zastąpił wirus, a okupacyjne opresje - przymusowa izolacja i strach przed choroba:

Siekiera, motyka, dureń, świrus,

Dopadł nas koronawirus (Siekiera 13).

3 Przykładowo, na stronie demotywatory.pl w kwietniu 2021 r. znajdowało się 29 grafik z przeróbkami piosenki Siekiera, motyka, o różnorodnej tematyce, czasem wykorzystujące zdjęcia z filmu Zakazane piosenki. 
Siekiera, motyka, beczka śledzi, Każdy w domu grzecznie siedzi.

Siekiera, motyka, gaz i prąd,

Niech ten wirus spieprza stąd! (Siekiera 13).

Siekiera, motyka, bimber piłem,

Więc się chyba odkaziłem.

Siekiera, motyka ja cię kręcę,

Myjcie co minuta ręce (Siekiera 5).

Siekiera, motyka, jest zaraza,

Prezydenta to nie zraża.

Siekiera, motyka, piłka, śledź,

Ty człowieku w domu siedź! (Siekiera 4 )

Współczesne kontrafaktury piosenki Siekiera, motyka nierzadko szczątkowe, ograniczające się do jednej lub dwóch zwrotek, stały się elementem e-folkloru, dzięki któremu „tradycyjne motywy, wątki czy gatunki, często będące już »na wymarciu«, nieoczekiwanie zyskały szanse na drugie życie" (Grochowski 2009: 9). W przypadku tej piosenki jest to życie kolejne. I po raz kolejny służy ona „oswajaniu traumy”, tym razem będącej skutkiem pandemii koronawirusa. Wykorzystywanie tekstów folkloru jako sposobów radzenia sobie z trudnościami powracało przy okazji różnych kataklizmów: powodzi, epidemii, ataków terrorystycznych i innych sytuacji traumatycznych, czyli zawsze wtedy, „kiedy w istniejącej strukturze społecznej lub kulturze pojawia się jakaś dezorganizacja, przemieszczenie, niespójność, innymi słowy, kiedy kontekst życia ludzkiego i działań społecznych traci jednorodność, koherencję oraz stabilność” (Hajduk-Nijakowska 2005: 19). Kontrafaktury Siekiery, motyki i towarzyszące im rysunki lub memy zwracają uwage na komiczny aspekt dramatycznej w sumie sytuacji, sprzyjają znalezieniu dystansu do aktualnych wydarzeń. Spełniają funkcje typowe dla folkloru - ujawniają postawy, uprzedzenia i lęki wobec obcych, nieznanych albo niezrozumiałych zjawisk bądź sytuacji (Krawczyk-Wasilewska 2009: 17).

Sytuację ludzi zmuszonych do domowej izolacji podczas pandemii można porównać do tej, w jakiej znaleźli się Polacy biorący udział w strajkach okupacyjnych w latach 8o. XX w. Różnica polega głównie na tym, że izolacja strajkujących stanowiła ich wybór, natomiast ta współczesna była narzucona przez władzę. W obu jednak przypadkach w grupach ludzi, zamkniętych w określonej przestrzeni, znużonych oczekiwaniem na powrót do normalności, mogło z jednej strony dochodzić do dramatycznych spięć, $\mathrm{z}$ drugiej zaś do wyzwolenia różnych formy ekspresji i zabawy. Opisując sytuację strajkujących Czesław Robotycki $\mathrm{w}$ artykule poświęconym folklorowi strajkowemu podkreślał, że powstające wówczas rymowane ballady, kuplety, piosenki, często na melodie popularnych szlagierów, powoływała do życia „spontaniczna akcja”. Powstająca w takich nie- 
codziennych warunkach twórczość „obliczona jest na działanie doraźne, stąd najczęstsza jej broń, to różne rejestry śmiechu. Apeluje, jak każda ludowa poezja, raczej do uczuć niż do intelektu" (Robotycki 1990: 46-47). Podobnie było z twórczością zrodzoną podczas „narodowej kwarantanny”.

Nowe wersje Siekiery, motyki z czasów pandemii mają cechy podobne do tych wcześniejszych, z lat okupacji i stanu wojennego. Są bardzo mocno osadzone w aktualnych wydarzeniach, opisują realia, sytuacje i elementy codzienności, które z upływem czasu przestają być zrozumiałe, np.:

Siekiera, motyka, piłka, gwóźdź,

Dam górala, puść mnie, puść (Ruth Buczkowski 1947: 65).

Siekiera, motyka, Białołęka,

Naród cierpi, lecz nie pęka (Głosy 1982: 73).

Siekiera, motyka, nie mam czasu,

Zamknę w Polsce drzwi do lasu (Siekiera 3).

Siekiera, motyka, oczy, wory,

Nie ma testów, nie ma chorych (Siekiera 3).

Pojawiają się $\mathrm{w}$ nich postacie ze świata polityki istotne $\mathrm{w}$ danym momencie historycznym. Nie zawsze padają ich nazwiska, co również może dodatkowo wpływać na nieczytelność tekstu po latach, np.:

Siekiera, motyka, styczeń, luty,

Hitler z Ducem gubią buty (Ruth Buczkowski 1947: 65).

Siekiera, motyka, ambasada,

Przegonimy Wojtka dziada (Głosy 1984: 73).

Siekiera, motyka i bimber blues,

Naczelnik Jarosław to jest tchórz (Siekiera 4).

Wspólną cechą różnych wersji są również słowa podtrzymujące na duchu i wyrażające wiarę w pokonanie wroga, np.:

Siekiera, motyka, bimber, alasz,

Przegra wojnę głupi malarz.

Siekiera, motyka, gaz i prąd,

Już niedługo pójdą stąd (Ruth Buczkowski 1947: 65).

Siekiera, motyka i car Lonia,

Macie wprawdzie już Kuronia, 
Macie także już Michnika,

Lecz w narodzie duch nie znika (Skoczek 2001: 518).

Siekiera, motyka, kwarantanna,

Już zaraza nas ogarnia.

Naród siedzi pod strzechami,

Ale przecież się nie damy (Siekiera 14).

Zasadnicza różnica pomiędzy wariantami Siekiery, motyki z różnych okresów polega na tym, że o ile w kontrafakturach okupacyjnych i tych z okresu stanu wojennego śmiech przeplata się z powagą, to w przypadku wersji pandemicznych mamy do czynienia wyłącznie z żartem, dowcipem, kpiną. Można tu przytoczyć spostrzeżenia socjologa Kazimierza Żygulskiego, który podkreślił istnienie „wspólnoty śmiechu” wytwarzającej w trudnych warunkach, takich jak klęska żywiołowa lub wojna, potrzebę komizmu. Spełnia on wówczas ważną funkcję: „przynajmniej w części przywraca grupom sytuacji krańcowej równowage psychiczną, jest dowodem panowania nad sytuacją, [...] integruje, odpręża, bawi” (Żygulski 1976: 143).

Analizując treść, okoliczności powstawania i żywotność kolejnych wariantów Siekiery, motyki można dopatrzyć się analogii do dowcipów, które bywają popularne w pewnym czasie, a potem ich aktualność gwałtownie spada, np. w związku ze zmianą sytuacji politycznej. W ich miejsce pojawiają się inne żarty, często wykorzystujące tę samą lub podobną strukturę i wątek, ale osadzone w nowych realiach i z innymi bohaterami, np. „głupiego milicjanta” zastępuje „głupia blondynka” (Kucharski 20o9: 36). Zbliżoną zasadę, wykorzystywania starego wzorca do tworzenia uaktualnionej wersji, odnajdujemy w wariantach omawianej piosenki z różnych okresów historycznych. W zwrotkach powstałych w sytuacji zagrożenia, czyli podczas okupacji, stanu wojennego i pandemii, opisane są aktualne realia, trudne warunki życia, wspomniane są konkretne miejsca, wydarzenia, postacie, a główną rolą tekstów jest wyrażenie sprzeciwu wobec okupanta, komunistycznej władzy bądź aktualnej sytuacji politycznej i społecznej. W zależności od tego, w jakich czasach wariant Siekiery, motyki powstał, opisywaną opresją jest łapanka, internowanie bądź przymusowa izolacja, a negatywnymi bohaterem Hitler, Jaruzelski lub ministrowie obecnego rządu.

Inaczej rzeczy wygląda w wersjach piosenki powstałych w czasach „normalności', zarówno po I, jak i II wojnie światowej. Tu dominują wątki obyczajowe, często ujęte $\mathrm{z}$ humorem, przy czym są to zwykle dwa tematy: relacje damsko-męskie oraz spożywanie alkoholu. Taki dobór treści może mieć związek z chęcią odreagowania wojennej traumy, a także nawiązywać do pierwszych wersji Siekiery, motyki, w których pojawiała się zachęta do „korzystania z życia, póki czas ”. Z początkiem XXI w. w związku z rosnącym dostępem do internetu, umożliwiającego praktycznie każdemu publikowanie swej twórczości, pojawiają się rymowanki polityczno-społeczne, nawiązujące do spraw znanych z mediów, takich jak działalność polityków, afery obyczajowe, podwyżki, ubożenie społe- 
czeństwa, emigracja. Są to zazwyczaj krótkie formy, które - podobnie jak dowcipy - wykorzystują ośmieszenie i szyderstwo do korygowania negatywnych zjawisk społecznych (Kucharski 2009: 30).

W kolejnych wariantach omawianej piosenki zachowana jest jej struktura, a wymiana elementów mająca na celu aktualizację treści wykorzystuje komizm rymu. Regułę stanowi przypadkowy dobór wyrazów będących kontynuacją incipitu „Siekiera, motyka...”. Nie ma znaczenia brak związku semantycznego poszczególnych rzeczowników, istotne jest to, aby wers rymował się z następnym, zawierającym główny przekaz, np.:

Siekiera, motyka, linka, drut, Już pan malarz jest kaput (Siekiera 10).

Siekiera, motyka, piłka, metal, Mamy swego Pinocheta (Głosy 1984: 73).

Siekiera, motyka, sznurek, trampek, Agentów łapie wujek Antek (Siekiera 12).

Siekiera, motyka, zlew i wanna, W naszym kraju kwarantanna (Siekiera 13).

Wyliczanie nie mających związku wyrazów samo w sobie nie byłoby śmieszne, ale ich zaskakujący dobór wywołuje często efekt komiczny. Przywołuje także skojarzenia z dziecięcymi wyliczankami, co dostrzegli niektórzy twórcy nowych rymowanek:

Siekiera, motyka, raz, dwa, trzy,

Dziś agentem jesteś ty! (Siekiera 12)

Sposobem na wzmocnienie efektu komicznego jest także wykorzystanie w tekstach wulgaryzmów. Pojawiają się one już w starych wersjach Siekiery, motyki, np. w cytowanym wcześniej tekście autorstwa Anny Jachniny (Posłuchajcie 1943: 4), gdzie są prawdopodobnie nie tylko żartem, ale i wyrazem złości. W wersjach współczesnych wulgaryzmy używane są częściej; zapewne nie tylko dla żartu i wzmocnienia wypowiedzi, ale też w związku z tym, że coraz powszechniej występują w codziennym języku:

Siekiera, motyka, bimber, siara,

Kto żyw z Polski wypierdala (Siekiera 12).

Suka, radiowóz, woda, gaz,

Chawu depe i jeszcze raz (Siekiera 4 ). 
Siekiera, motyka, bimber, wanna, wkurwia nas już kwarantanna (Siekiera 2).

Większość kontrafaktur Siekiery, motyki, pomijając wersje „pijackie” lub obsceniczne, możemy zaliczyć do folkloru politycznego. Są one reakcją na bieżące wydarzenia polityczne, gospodarcze i społeczne. Należą do folkloru interspołecznego, funkcjonującego z równym powodzeniem we wszystkich grupach wiekowych, zawodowych i innych. Nie ma tu znaczenia tożsamość autorów; nawet jeśli byli oni znani, to ich teksty wprowadzone w obieg społeczny ulegały anonimizacji i w wielu wariantach dalej toczyły swój folklorystyczny żywot (Łysiak 1990: 15).

Kontrafaktury Siekiery, motyki powstałe w różnych okresach historycznych różnią się też sposobem transmisji. O ile dawniej stanowiły element folkloru tradycyjnego, teraz należą do e-folkloru. Pierwotnie funkcjonowały przede wszystkim w wersji ustnej i miały charakter meliczny. Wersje współczesne, w tym także „pandemiczne”, istnieją wyłącznie w pisemnej lub obrazkowej formie przekazu, pomimo to są one mniej trwałe i jeżeli nie zostaną w porę zarchiwizowane, zginą w morzu internetowych newsów, które - jak pisze Wioletta Wróblewska - mają to do siebie, że

[...] szybko znikają z obiegu, ustępując miejsca nowym, bardziej atrakcyjnym przykładom. Związek z chwilą obecną, szybka dezaktualizacja tematów oraz konkretnych tekstów uchodzi za właściwość kultury popularnej, która nie służy nauce, utrwalaniu wzorców zachowań, norm moralnych danej grupy, lecz przede wszystkim zabawie (Wróblewska 2005: 15).

Próbując wyjaśnić fenomen żywotności piosenki Siekiera, motyka warto zastanowić się, jakie czynniki miały wpływ na to, że ciągle powstają jej nowe wersje. Niewątpliwie ważną rolę odegrał film Zakazane piosenki, pierwszy polski obraz, jaki zrealizowano po II wojnie światowej. Jego atrakcyjność, patriotyczny przekaz, a później częste emitowanie w telewizji, miały niewątpliwie wpływ na to, że okupacyjna wersja piosenki stała się powszechnie znana. Nie bez znaczenia była też wpadająca w ucho melodia, w której nostalgiczny nastrój przeplata się $\mathrm{z}$ tanecznym rytmem. Istotna jest także forma literacka piosenki: pararelizm składniowy, polegający na użyciu szeregu przypadkowych rzeczowników w co drugim wersie, ułatwia układanie rymów i tworzenie nowych zwrotek. Chwytliwy incipit wyzwala kreatywność autorów, a powielanie utartego schematu kompozycyjnego daje nieograniczone możliwości tworzenia aktualnych wersji. Powiązanie treści z walką, opozycją i kpiną z wrogów w czasach II wojny światowej skutkuje tym, że do dziś Siekiera, motyka jest kojarzona z ruchem oporu i ośmieszaniem przeciwników. Stąd współcześnie, najwięcej wersji piosenki służy do krytycznego komentowania, wyśmiewania, a także oswajania nowej, nieprzyjaznej rzeczywistości. 


\section{BIBLIOGRAFIA}

Adamczyk, W., Brutter, R. (2013). Czas konspiry [odcinek serialu telewizyjnego]. W: Ranczo, sezon 7, odc. 89. Studio A. Pobrano z: https://vod.tvp.pl/video/ranczo,odc-89-czaskonspiry,10630859

Adrjański, Z. (1997). Złota księga pieśni polskich: pieśni, gawę̨y, opowieści. Warszawa: Volumen.

Dubrowska, M. (2017, 28 lipca). Te piosenki śpiewano w powstaniu warszawskim. Chętnie wykonuje się je do dziś [artykuł na portalu wyborcza.pl]. Pobrano z: http://cojestgrane24.wyborcza.pl/cjg24/1,13,22158262,147814

Głosy zza muru. Wiersze i piosenki z obozów dla internowanych (grudzień 81-listopad 82) (1984). Warszawa: Wydawnictwo.

Głuszak, K. A. (2014). Muzyka i piosenka popularna jako narzędzia opozycji politycznej w Polsce w latach 8o. XX wieku. Praca doktorska pod kierunkiem prof. dr. hab. Ryszarda Zięby. Warszawa: Uniwersytet Warszawski.

Grochowski, P. (2009). Wstęp. Słów kilka o ubocznych skutkach ptasiej grypy. W: G. Gańczarczyk, P. Grochowski (red.), Folklor w dobie Internetu (s. 7-11). Toruń: Wydawnictwo Naukowe Uniwersytetu Mikołaja Kopernika.

Hajduk-Nijakowska, J. (2005). Żywioł i kultura. Folklorystyczne mechanizmy oswajania traumy. Opole: Uniwersytet Opolski, Opolskie Towarzystwo Przyjaciół Nauk.

Jachnina, A., Woźniak, M. (1975, 16 lutego). Śmiechem zabijać wojnę. Czas. Tygodnik Społeczny, 1(3), 24 .

Jackowski, A. (1990). Folklor kontestacji. Polska Sztuka Ludowa, 44(2), 11-14.

Krawczyk-Wasilewska, V. (2009). E-folklor jako zjawisko kultury digitalnej. W: G. Gańczarczyk, P. Grochowski (red.), Folklor w dobie Internetu (s. 15-22). Toruń: Wydawnictwo Naukowe Uniwersytetu Mikołaja Kopernika.

Kucharski, A. (2009). Struktura i treść jako wyznaczniki komizmu tekstów humorystycznych. Lublin: Wydawnictwo Uniwerystetu Marii Curie-Skłodowskiej.

Łysiak, W. (1990). Oblicza folkloru- folklor polityczny. Polska Sztuka Ludowa, 44(2), 15-19.

Polka siedzonka (1932, 26 czerwca). Żótta Mucha Tse-Tse, 4(28), 3.

Postuchajcie ludzie... (1943). Warszawa: Wydawnictwo KOPR-u.

Prositem ja przy jabłoni. Co użyjem to dla nas. Dwie piosenki żotnierskie (1920). Warszawa: F. Grąbczewski i I. Rzepecki.

Robotycki, C. (1990). Sztuka a vista. Folklor strajkowy. Polska Sztuka Ludowa, 44(2), 44-49.

Ruth Buczkowski, M. (1947). Warszawski dowcip w walce 1939-1944. Warszawa: Gebethner i Wolff.

Siekiera, motyka...(1989, 23 czerwca), Gazeta Wyborcza, 34, 4.

Siekiera, motyka, rock, hip hop, folk (2003, 18 marca) [artykuł na portalu Życie Warszawy.pl]. Pobrano z: http://www.zw.com.pl/artykul/139743.html

Skoczek, A. (2001). Poezja stanu wojennego jako tekst kultury. Napis, 7, 509-522.

Sławiński, J. (red.) (1988). Stownik terminów literackich, Wrocław, Warszawa, Kraków, Gdańsk, Łódź: Zakład Narodowy Imienia Ossolińskich Wydawnictwo.

Straszewicz, L. (1946). Śmiech w kajdanach. Kawaty warszawskie w czasach okupacji. [Brak miejsca wydania].

Szarota, T. (2010). Okupowanej Warszawy dzień powszedni. Warszawa: Czytelnik.

Szubrycht, J. (2020, 27 lutego). Nagle przy stole zaczynała opowiadać, jak wyglądały święta w Auschwitz [artykuł na portalu wyborcza.pl]. Pobrano z: https://wyborcza.pl/7,113768,2563310o, siekiera-motyka-szarlotka-rodzinna-tajemnica-w-cieniu-wielkiej.html

Szymalski, A. (red.) (1986). Opowieść o piosence. Wspomnienia o piosence czasów wojny. Warszawa: Krajowa Agencja Wydawnicza. 
Wieczorkiewicz, S. (1974). Gwara warszawska dawniej i dziś. Warszawa: Państwowy Instytut Wydawniczy.

Wróblewska, V. (2005). Współczesny folklor słowny. W: A. Mianecki, A. Osińska, L. Podziewska (red.), Folklor w badaniach współczesnych (s. 7-15). Toruń: Wydawnictwo Naukowe Uniwersytetu Mikołaja Kopernika.

Załęski, G. (1958). Satyra w konspiracji. Warszawa: Ministerstwo Obrony Narodowej.

Żygulski, K. (1976). Wspólnota śmiechu. Studium socjologiczne komizmu. Warszawa: Państwowy Instytut Wydawniczy.

\section{INTERNETOWE ŹRÓDŁA TEKSTÓW}

Siekiera 1. Cyfrowa Biblioteka Piosenki Polskiej [serwis internetowy]. Pobrano z: https://bibliotekapiosenki.pl/utwory/Siekiera_motyka_(Siekiera_motyka_bimbru_szklanka)/tekst [dostęp: 2021-03-08].

Siekiera 2. Demotywatory.pl [serwis internetowy]. Pobrano z: Siekiera,motyka,bimber,wannawku*wia już nas kwarantanna [dostęp: 2021-03-08].

Siekiera 3. Demotywatory.pl [serwis internetowy]. Pobrano z: https://demotywatory.pl/4993861/ Krotko-o-obecnej-sytuacji-[dostęp: 2021-03-08].

Siekiera 4. Facebook.pl [serwis internetowy]. Pobrano z: https://www.facebook.com/Farfotzle [dostęp: 2021-03-08].

Siekiera 5. Facebook.pl [serwis internetowy]. Pobrano z: https://www.facebook.com/zespol.tornado. podlaskie [dostęp: 2021-03-08].

Siekiera 6. Kafeteria.pl [serwis internetowy]. Pobrano z: https://f.kafeteria.pl/temat-6457973tworzymy-nowe-piosenki-przerobki-znanych/ [dostęp: 2021-03-08].

Siekiera 7. Onet.pl [serwis internetowy]. Pobrano z: https://zapytaj.onet.pl/Category /027,009/2,32138271,Siekiera_motyka.html [dostęp: 2021-03-08].

Siekiera 8. Stare Melodie [serwis internetowy]. Pobrano z: https://staremelodie.pl/piosenka/39o1/ Siekiera_motyka [dostęp: 2020-04-20].

Siekiera 9. Stare Melodie [serwis internetowy]. Pobrano z: https://staremelodie.pl/piosenka/3947/ Co_użyjem,_to_dla_nas [dostęp: 2021-03-08].

Siekiera 10. Teksty.org [serwis internetowy]. Pobrano z: https://teksty.org/lao-che,godzina-w, tekst-piosenki [dostęp: 2021-03-08].

Siekiera 11. Teksty.org [serwis internetowy]. Pobrano z: https://teksty.org/piersi,marsz-kpn,tekstpiosenki [dostęp: 2021-03-08].

Siekiera 12. Trójmiasto.pl [serwis internetowy]. Pobrano z: https://przerobka.trojmiasto.pl/ Niedzielne-protesty-przed-sadami-w-Trojmiescie-n114981.html?strona=15 [dostęp: 2020-04-20].

Siekiera 13. Twitter.pl [serwis internetowy]. Pobrano z: https://twitter.com/egassowska/status/ 1243892748823990275 [dostęp: 2021-03-08].

Siekiera 14. Twitter.pl [serwis internetowy]. Pobrano z: https://twitter.com/SolakKrzysztof/status/ 1244978421584859136 [dostęp: 2020-04-20]. 